\title{
Study of Independence Student's Online Learning During Covid-19 Pandemic
}

\author{
Wiwin Dwi Winarti ${ }^{1}$, Dian Septi Nur Afifah ${ }^{2}$, Linda Pebriani, ${ }^{3}$ Ika Mariana \\ Putri $^{4}$, Imam Sukwatus Suja' ${ }^{5}$ \\ ${ }^{1}$ Mathematics Education, Junior High School 5 Tulungagung, Jl. Rejosari, \\ Kedungsoko, Tulungagung, Indonesia \\ ${ }^{2,3,4,5}$ Mathematic Education, Bhinneka PGRI University, J1. Mayor Sujadi Timur no. 7 \\ Plosokandang, Tulungagung, Indonesia
}

wiwinwinarti1968@gmail.com

\begin{abstract}
This research aims to describe the perceptions of independence online learning during Covid-19 Pandemic. This research was conducted at Junior High School 5 Tulungagung. Data collection techniques in this research were observation and questionnaire. The main instrument is researcher itself, the supporting instrument are observation notes and questionnaire sheets. The data validity uses in this research is extension of observation. Data analysis based on indicators of learning independence which include self-confidence, discipline, initiative, responsibility, and motivation. The result of this research indicate the self-confidence indicator, $28 \%$ students stated that they were always confident, $30 \%$ stated often, $20 \%$ stated sometimes, $13 \%$ stated rarely, and $9 \%$ stated never. In discipline indicator, $75 \%$ of students stated that they were always discipline, $3 \%$ stated sometimes, $1 \%$ stated rarely and never. In initiative attitude indicators, $35 \%$ students stated that they always had the initiative, $34 \%$ stated often, $22 \%$ stated sometimes, $3 \%$ stated rarely and the remaining $6 \%$ stated never. In responsibility attitude indicator, $51 \%$ students stated that they always had a responsibility, $25 \%$ stated often, $20 \%$ stated sometimes, $1 \%$ stated rarely and the remaining 3\% stated never. In motivation indicators, $91 \%$ students stated that they always had a motivation and the remaining $9 \%$ stated often.
\end{abstract}

\section{Introduction}

Covid-19 pandemic that attacked the world, include in Indonesia has caused many changes in various aspects of life, especially in the economic and education sectors. According to Kompas 28/03/2020 the impact of Covid-19 virus occured in various fields such as social, economic, tourism, and education [1]. Covid-19 pandemic requires all citizen to stay at home to stop its spread, including in education. School activities also change at home, so this bring up a new thing called online learning. This is in line with a circular from goverment regarding the learning system during pandemic, which the learning process is carried out at home through online learning to provide meaningful learning experiences for students [1]. Online learning can connect student with learning resources (database, expert/instructor, library) that are physically sepatare or even far apart but can communicate, interact or collaborate (directly/synchronously and indirectly/ asynchronously) [2]. Online system is the right alternatice if applied during this pandemic. Some of the advantages from online learning is students allows to have 
the flexibility time in learning, so they can study anytime and anywhere [3]. Other than that online learning can overcome problems regarding distance, example student do not have to go to school first to study. There are no restrictions and can cover a large area [4]. This online system usually use social media such as WhatsApp, Google Classroom, Zoom and other applications that allow active comunication between teacher and students in teaching learning activities. One of the successful factors during online learning is independence attitude of student learning.

Learning independene comes from independent and learning word. Independence can be interpreted as a condition that allow a person to organize and direct themselves according to their development level [5]. Meanwhile, according to the Big Indonesian Dictionary, independence is a state of being able to stand alone without depending another people. Yamin [6] stated that independence learning is learning that free to determine direction, plans, sources and decision in achieving academic goals, but not free from the diversity rules, state or communisty customs. Based on several definition above, learning independence is students' effort to achieve learning goals with a sense of responsibility without depending on others.

Learning independence's indicator according to [6] are not dependent on others, self-confidence, dicipline, responsibility, self control. According to chabib, learning independence's characteristic are (1) being able to think critically, creatively, and innovatively, (2) not being easily influenced by other people's opinions, (3) not running away or avoiding problems, (4) solve the problems by thinking deeply, (5) if there's a problem, they can solve the problem by themself without asking for help, (6) do not feel inferior if they become different form others, (7) try to work with diligence and discipline, (8) responsible with their own action. As for some learning independence's indicator according to Mudjiman [7] consist of a confident attitude, active in learning, discipline, and responsibility in learning.

In addition, according to [8] stated that self-confidence has a relationship with learning independence, if a person has high self-confidence, this can increase their learning independence and otherwise. Some other attitudes that affect in learning independence are discipline, initiative, responsibility, and motivation. According to [9] stated that there is a very strong relationship between learning independence and students' independence attitude. Meanwhile, [10] identified the character of learning independence into five types, namey (1) self-confidence, (2) not relaying on other people, (3) initiative, (4) responsibility, (5) having a high motivation to achieve. Based on this description, the learning dependence's indicator that used in this research are self-confidence, discipline, initiative, responsibility, and motivation.

Several previous research about students' learning independence among others, Suid... research about anylisis of students' learning independence in the learning process in 3rd class Banda Aceh elementary school, Maksum... research about the analysis of students' learning independence profile in institution and yet there was none who research about the Independence Student's Online Learning During Covid19 Pandemic. Therefore it is necessary to conduct research about study of Student's Online Learning During Covid-19 Pandemic.

\section{Method}

This research is a qualitative desciptive research that aims to explain factually about students' learning independence during the covid-19 pandemic. The research was conducted at Junior High School 5 Tulungagung in 8th class. There are 22 respondents in this research. There are two instruments in this research, the main instrument and the supporting instrument. The main instrument in this research is researcher themself, where the researcher as the planner, data collector, analyzer, data interpreter and reporting the research result. In this case the researcher as the main instrument will dig up information on interesting findings that may arise in this study. While the supporting instrument in this research are the observation note sheet and the student learning independence questionnaire. Before the research's instrument used, the interument had been reviewed or assessed by expert, namely 
mathematics education lecturers with doctoral degrees. Regarding the validity used include aspect of the clarity of the language used, the suitability from the instrument items with aspect of learning independence. Data collection was carried out by providing opportunity to students as a subject to fill the learning independence questionnaire. Each statement given 5 choice answers there are always, often, sometimes, rarely, and never. The data vaidity test that used in this research is by extension of observation. Data analysis carried out included data reduction, data presentation and drawing conclusion.

\section{Result and Discussion}

In this research, learning independence was seen from 5 aspects, self confidence, discipline, initiative, resonsibility and motivation. In each aspect there are several indicators. The indicators in self confidence are enthusiasm in learning participating, not ashamed to ask question which they are not understand, not afraid when expressing opinion and comment on other students' opinion. The indicators in discipline are trying to obey the rules, not doing anything that can break the rules, students' knowing the rules and regulation that apply, students' feeling afraid to violate the existing regulation. The indicators in initiative are students' feeling challenged to find out more about the material presented by the teacher, students' need to read the supporting material book that has been delivered with their teacher so they can increases their knowledge, students' have their own way to making the material easier for them to learn, students' have the desire to try to practice the difficult questions. The indicators in responsibility are students trying to do school assignment by themself, students trying to do the task until successful, students trying to collect assigments on time, after answering the test students did not just ignore the test questions and cared whether the students could answer or not, students dare to responsibility with their anwers to the assignment given by teacher. The indicators in motivation are students' having a desire to get a good value, students' having purpose to succeed in future, students' having a desire to achieve good value in learning to make their parents proud of them. The following are the result of each indicator. In confident attitude with indicator of enthusiasm in participating online learning, 45\% stated always, $40 \%$ stated often, $9 \%$ stated sometimes, $4 \%$ stated rarely. In the indicator that they are not ashamed to ask question which they are not understand, 27\% stated always, $22 \%$ stated often, 31\% stated sometimes, $13 \%$ stated rarely and $4 \%$ stated never. In indicator that they are not afraid when expressing opinion, $27 \%$ stated always, $31 \%$ stated often, $18 \%$ stated sometimes, $13 \%$ stated rarely, $2 \%$ stated never. In indicator comment on other students' opinion, $13 \%$ stated always, $22 \%$ stated often and sometimes, $18 \%$ stated rarely and $22 \%$ stated never. This description can be shown in a table below

Table 1. Confident Indicators Result

\begin{tabular}{clccccc}
\hline No. & Statement & Always & Often & Sometimes & Rarely & Never \\
\hline 1 & Enthusiasm in learning participating & $45 \%$ & $40 \%$ & $9 \%$ & $4 \%$ & \\
2 & Not ashamed to ask question which they are not understand & $27 \%$ & $22 \%$ & $31 \%$ & $13 \%$ & $4 \%$ \\
3 & Not afraid when expressing opinion & $27 \%$ & $31 \%$ & $18 \%$ & $13 \%$ & $2 \%$ \\
4 & Comment on other students' opinion & $13 \%$ & $22 \%$ & $22 \%$ & $18 \%$ & $22 \%$ \\
\hline \multicolumn{2}{c}{ Average } & $28 \%$ & $30 \%$ & $20 \%$ & $3 \%$ & $9 \%$ \\
\hline
\end{tabular}

In general, students' confident attitude in online learning during covid-19 pandemic can be shown in this following picture 


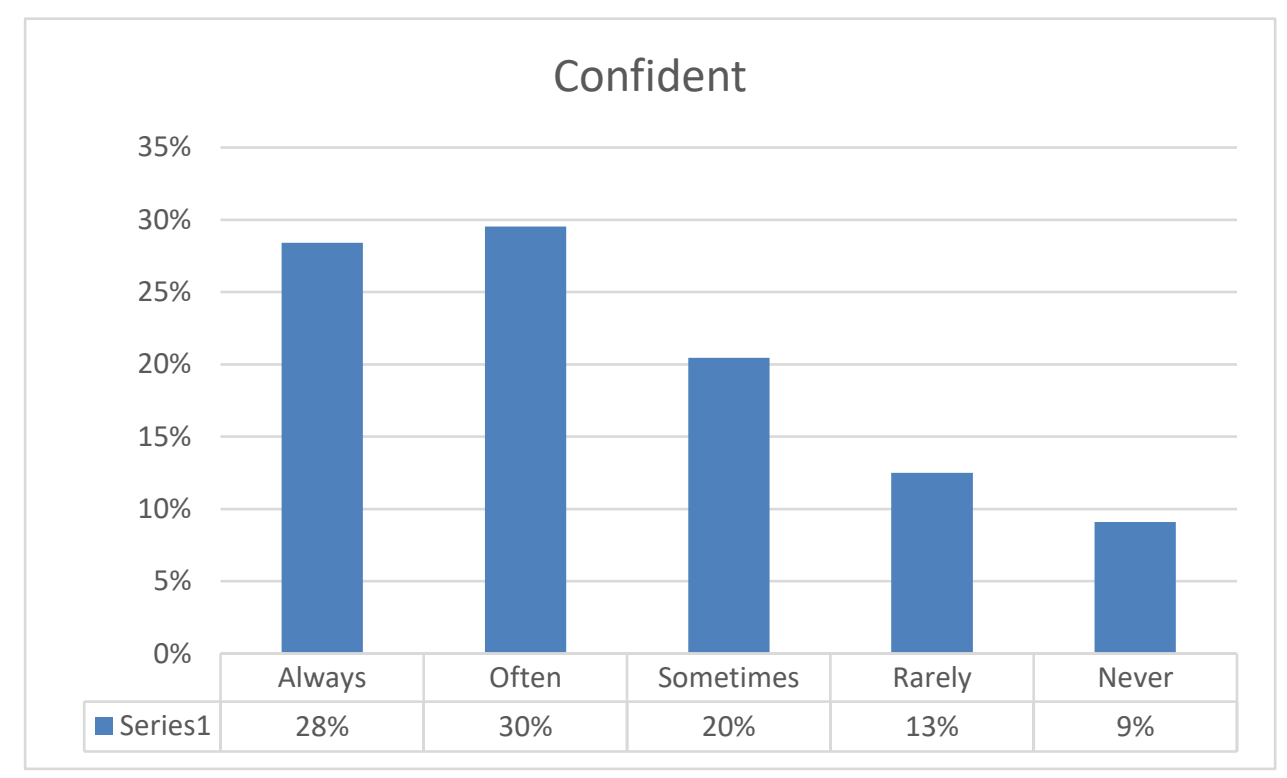

Picture 1. Confident diagram result

The table shows that $28 \%$ students stated always, $30 \%$ stated often, $20 \%$ stated sometimes, $13 \%$ stated rarely and 9\% stated never felt confident in online learning during covid-19 pandemic.

In disciplined attitude with indicator of trying to obey the rules, $72 \%$ stated always, $22 \%$ stated often and $4 \%$ stated sometimes. In indicator not doing anything that can break the rules, $63 \%$ stated always, $22 \%$ stated often, $4 \%$ stated sometimes, rarely and never. In indicator of students' knowing the rules and regulation that apply, $81 \%$ stated always, $13 \%$ stated often, $4 \%$ stated sometimes. In indicator of students' feeling afraid to violate the existing regulation, $81 \%$ stated always, $18 \%$ stated often. This description can be shown in a table below.

Table 2. Discipline Indicators Result

\begin{tabular}{clccccc}
\hline No. & \multicolumn{1}{c}{ Statement } & Always & Often & Sometimes & Rarely & Never \\
\hline 1 & Trying to obey the rules & $72 \%$ & $22 \%$ & $4 \%$ & & \\
2 & Not doing anything that can break the rules & $63 \%$ & $22 \%$ & $4 \%$ & $4 \%$ & $4 \%$ \\
3 & Students' knowing the rules and regulation that apply & $81 \%$ & $13 \%$ & $4 \%$ & & \\
4 & students' feeling afraid to violate the existing regulation & $81 \%$ & $22 \%$ & $18 \%$ & $18 \%$ & \\
\cline { 2 - 6 } & Average & $75 \%$ & $19 \%$ & $3 \%$ & $1 \%$ & $1 \%$ \\
\hline
\end{tabular}

In general, students' discipline attitude in online learning during covid-19 pandemic can be shown in this following picture. 


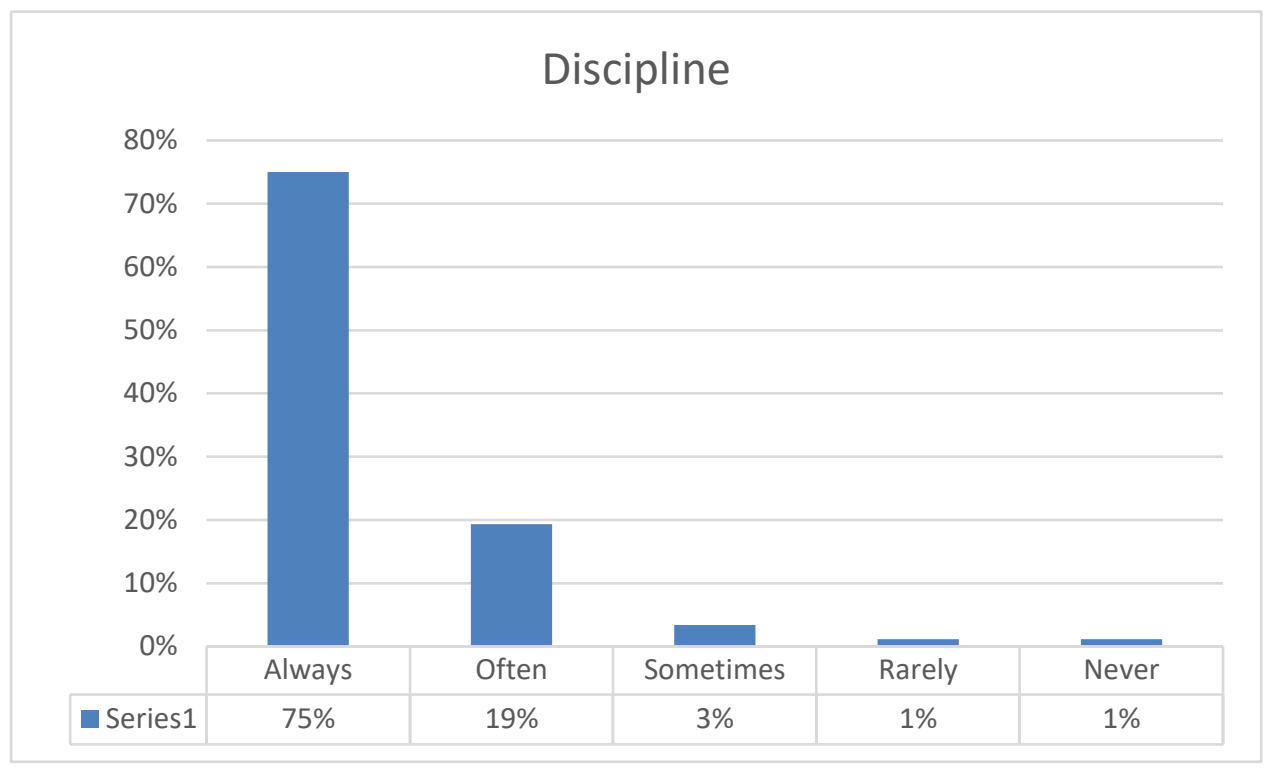

Picture 2. Discipline diagram result

The table shows that $75 \%$ students' stated always, $19 \%$ stated often, $3 \%$ stated sometimes, $1 \%$ stated rarely and never felt discipline in online learning during covid-19 pandemic.

In initiative attitude with indicator of students' feeling challenged to find out more about the material presented by the teacher, $32 \%$ stated always, $36 \%$ stated often, $23 \%$ stated sometimes, and the remaining 9\% stated they never feel challenged to know more about the material which is presented by their teacher. In indicator of students' need to read the supporting material book that has been delivered with their teacher so they can increases their knowledge, 36\% stated always, 50\% stated often, $14 \%$ stated sometimes they feel if they need to read a supporting material book. In indicator of students' have their own way to making the material easier for them to learn, 59\% stated always, $23 \%$ stated often, $9 \%$ stated sometimes, and the remaining $5 \%$ stated rarely and never. In indicator of students' have the desire to try to practice the difficult questions, $14 \%$ stated always, $27 \%$ stated often, $41 \%$ stated sometimes and the remaining $9 \%$ rarely and never have the desire to try to practice the difficult questions. This description can be shown in a table below.

Table 3. Initiative Indicators Result

\begin{tabular}{llccccc}
\hline No. & \multicolumn{1}{c}{ Statement } & Always & Often & Sometimes & Rarely & Never \\
\hline 1 & $\begin{array}{l}\text { Students' feeling challenged to find out more about } \\
\text { the material presented by the teacher }\end{array}$ & $32 \%$ & $36 \%$ & $23 \%$ & & $9 \%$ \\
2 & $\begin{array}{l}\text { Students' need to read the supporting material book } \\
\text { that has been delivered with their teacher so they can } \\
\text { increases their knowledge }\end{array}$ & $36 \%$ & $50 \%$ & $14 \%$ & & \\
3 & $\begin{array}{l}\text { Students' have their own way to making the material } \\
\text { easier for them to learn }\end{array}$ & $59 \%$ & $23 \%$ & $9 \%$ & $5 \%$ & $5 \%$ \\
\hline & $\begin{array}{l}\text { Students' have the desire to try to practice the } \\
\text { difficult questions }\end{array}$ & $14 \%$ & $14 \%$ & $41 \%$ & $9 \%$ & $9 \%$ \\
\hline Average & $35 \%$ & $34 \%$ & $22 \%$ & $3 \%$ & $6 \%$ \\
\hline
\end{tabular}


In general, the students' initiative in online learning during covid-19 pandemic can be shown in this following pictur

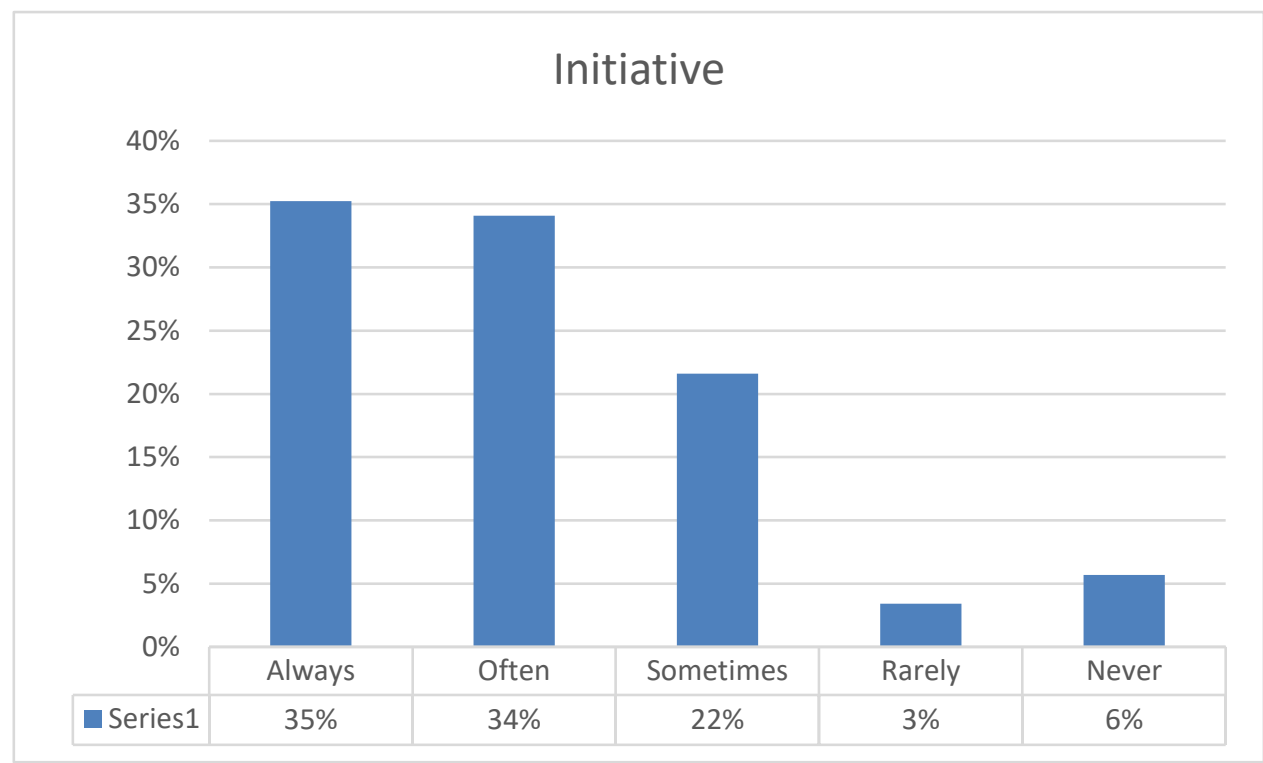

Picture 3. Initiative diagram result

The diagram shows that $35 \%$ students' stated always, $34 \%$ stated often, $22 \%$ stated sometimes, $3 \%$ stated rarely and the remaining $6 \%$ stated that students' never had initiative in online learning during covid-19 pandemic.

In responsibility attitide with indicators of students trying to do school assignment by themself, $41 \%$ stated always, $36 \%$ stated often and $23 \%$ stated sometimes. In indicator of students trying to do the task until successful, 59\% stated always, $27 \%$ stated often and $14 \%$ stated sometimes. In indicator of students trying to collect assigments on time, 64\% stated always, $23 \%$ stated often, and the remaining $14 \%$ stated sometimes. In indicator of after answering the test students did not just ignore the test questions and cared whether the students could answer or not, $41 \%$ states always, $9 \%$ stated often, $36 \%$ stated sometimes, $5 \%$ stated rarely and $9 \%$ stated never. In indicator of students dare to responsibility with their anwers to the assignment given by teacher, 50\% stated always, $32 \%$ stated often, $14 \%$ stated sometimes and the remaining 5\% stated never. This description can be shown in a table below.

Table 4. Responsibility Indicators Result

\begin{tabular}{llccccc}
\hline No. & \multicolumn{1}{c}{ Statement } & Always & Often & Sometimes & Rarely & Never \\
\hline 1 & students trying to do school assignment by themself & $41 \%$ & $36 \%$ & $23 \%$ & & \\
2 & $\begin{array}{l}\text { students trying to do the task until successful } \\
\text { students trying to collect assigments on time }\end{array}$ & $59 \%$ & $27 \%$ & $14 \%$ & & \\
4 & $64 \%$ & $23 \%$ & $14 \%$ & & \\
$\begin{array}{l}\text { after answering the test students did not just ignore } \\
\text { the test questions and cared whether the students } \\
\text { could answer or not }\end{array}$ & $41 \%$ & $9 \%$ & $36 \%$ & $5 \%$ & $9 \%$ \\
$\begin{array}{l}\text { students dare to responsibility with their anwers to } \\
\text { the assignment given by teacher }\end{array}$ & $50 \%$ & $32 \%$ & $14 \%$ & $5 \%$ \\
\hline$\quad$ Average & $51 \%$ & $25^{\wedge}$ & $20 \%$ & $1 \%$ & $3 \%$ \\
\hline
\end{tabular}


In general, students' responsibility attitude in online learning during covid-19 pandemic can be shown in this following picture

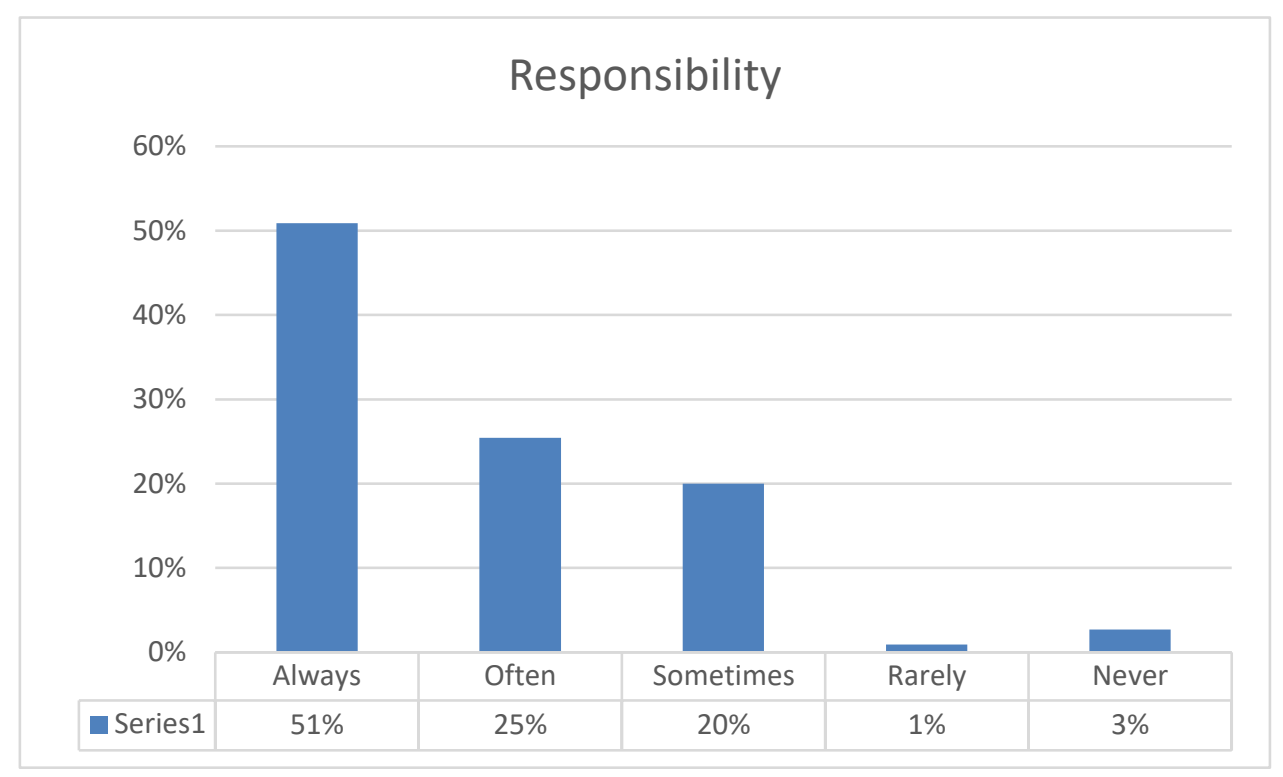

Picture 4. Responsibility diagram result

The diagram shows that $51 \%$ of students stated that they always had a sense of responsibility in online learning during covid-19 pandemic, $25 \%$ stated often, $20 \%$ stated sometimes, $1 \%$ stated rarely and the remaining $3 \%$ stated never.

In motivational attitude with indicator of students' having a desire to get a good value, $95 \%$ stated always, and the remaining $5 \%$ stated often. In indicator of students' having purpose to succeed in future, $91 \%$ stated always and the remaining $9 \%$ stated often. In indicator of students' having a desire to achieve good value in learning to make their parents proud of them, $86 \%$ stated always, and the remaining 14 stated often. This description can be shown in a table below.

Table 5. Motivation Indicators Result

\begin{tabular}{|l|l|c|c|c|c|c|}
\hline No. & \multicolumn{1}{|c|}{ Statement } & Always & Often & Sometimes & Rarely & Never \\
\hline 1 & students' having a desire to get a good value & $95 \%$ & $5 \%$ & & & \\
\hline 2 & students' having purpose to succeed in future & $91 \%$ & $9 \%$ & & & \\
\hline 3 & $\begin{array}{l}\text { students' having a desire to achieve good value in } \\
\text { learning to make their parents proud of them }\end{array}$ & $86 \%$ & $14 \%$ & & & \\
\hline \multicolumn{2}{|c|}{ Average } & $91 \%$ & $9 \%$ & $0 \%$ & $0 \%$ & $0 \%$ \\
\hline
\end{tabular}

In general, students' motivational attitude in online learning during covid-19 pandemic can be shown in this following picture 


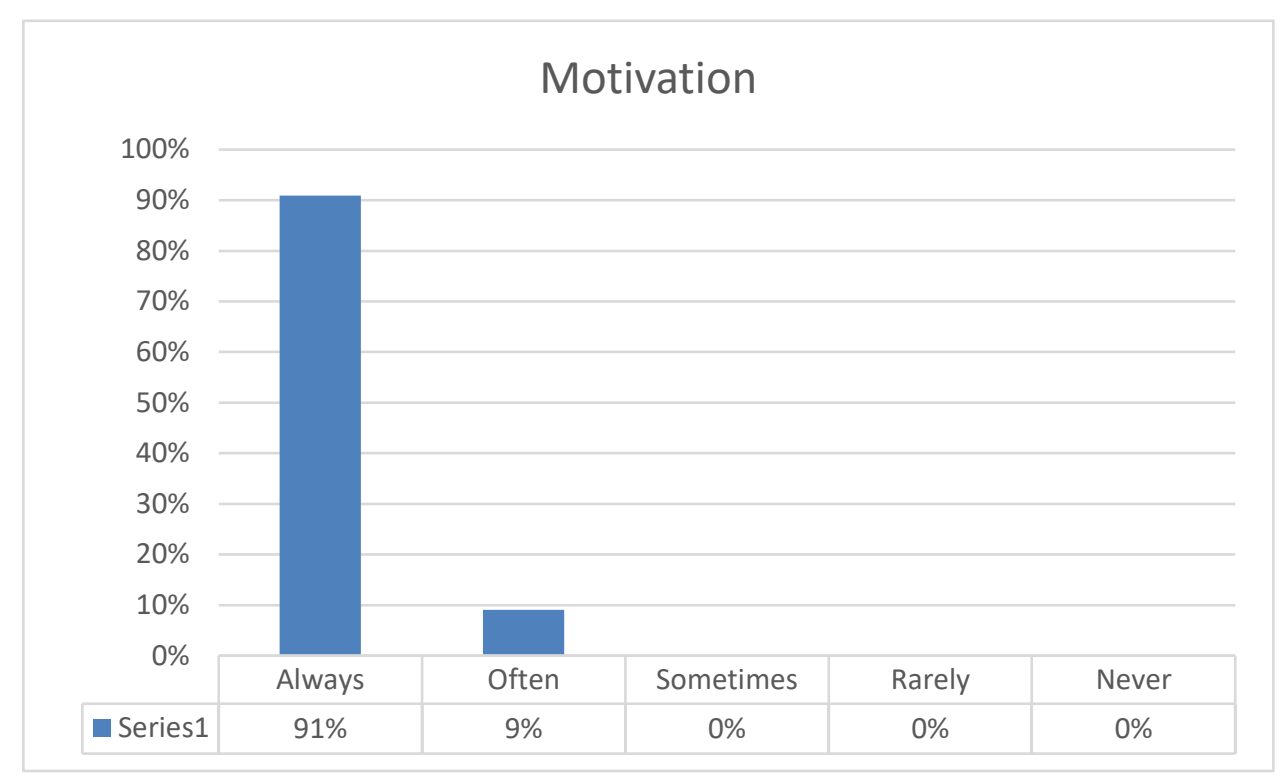

Picture 5. Motivation diagram result

The diagram shows that $91 \%$ students stated that they always had a motivation sense while carrying out learning during covid-19 pandemic, and the remaining $9 \%$ stated often.

Based on the description above, it can be concluded that during the covid-19 pandemic, many of student have independence learning, especially in the 8th grade in junior high school 5 Tulungagung on mathematic lesson. In indicator of self confidence, $28 \%$ students stated that they were always confident while learning online during covid-19 pandemic, 30\% stated often, $20 \%$ stated sometimes, $13 \%$ stated rarely and $9 \%$ stated that they never felt confident in online learning during covid-19 pandemic. This mean that student have learning independence in indicator of selfconfidence. This accordance with the opinion of [8] which stated that self confidence has a relationship with independence learning, if someone has high self confidence than this can increase their leaening independence and otherwise.

In discipline indicators, $75 \%$ students stated that they always discipline while online learning during covid-19 pandemic, $19 \%$ stated often, $3 \%$ stated sometimes and $1 \%$ stated rarely and never feel discipline in online learning during covid-19 pandemic. This mean that student have learning independence on discipline indicator. This is accordance with the opinion of Chabib [11] which stated that a person is considered have learning independence if they have a discipline attitude in doing something.

In initiative attitude indicators, $35 \%$ students stated that they always have an initiative while online learning during covid-19 pandemic, 34\% stated often, $22 \%$ stated sometimes, $3 \%$ stated rarely and the remaining $6 \%$ stated they never have an initiative in online learning during covid-19 pandemic. This 
shows that in online learning during covid-19 pandemic, students have learning independence with initiative indicator. This is accorcance with the opinion from [6] which stated that one of the indicators of learning independence is the presence of one's own initiative.

In responsibility attitude indicators, $51 \%$ students stated that they always have a sense of responsibility in online learning during covid-19 pandemic, $25 \%$ stated often, $20 \%$ stated sometimes, $1 \%$ stated rarely and $3 \%$ stated they never have a sense of responsibility while online learning during covid-19 pandemic. It can be seen that in online learning during covid-19 pandemic, most student feel responsible for their assignments. This shows that students have an learning independence on responsibility indicators. This is accordance with [10] which stated that one of the characteristics of a person's learning independence is the nature of responsibility for what they are doing.

In motivation indicators, $91 \%$ students stated that they always have a sense of motivation while online learning during covid-19 pandemic and the remaining $9 \%$ stated often. It can be seen that most students have motivation during online learning. This shows that almost all of students have learning independence, especially in motivation indicators. This is accordance with suparno .. which stated that the characteristic of a person who has learning independence is having a high sense of motivation in learning.

\section{Conclusion}

Based on data description above, it can be concluded that most of the students have a learning independence in online learning during covid-19 pandemic. This can be shown by the lots of percentage in each indicator of learning independence. As for some learning independence indicators are self confidence, discipline, initiative, responsibility and motivation. In self confidence indicator, 28\% students stated always, $30 \%$ stated often, $20 \%$ stated sometimes, $13 \%$ stated rarely and $9 \%$ stated never. In discipline indicators, $75 \%$ students stated always, $19 \%$ stated often, $3 \%$ stated sometimes, $1 \%$ stated rarely and never. In initiative indicators, 35\% stated always, 34\% stated often, $22 \%$ stated sometimes, $3 \%$ stated rarely and $6 \%$ stated never. In resonsibility indicator, 51\% stated always, $25 \%$ stated often, $20 \%$ stated sometimes, $1 \%$ stated rarely and the remaining $3 \%$ stated never. In motivation indicators, $91 \%$ stated always, and remaining $9 \%$ stated often.

\section{References}

[1] wahyu A. Fatma Dewi, "Dampak Covid -19 Terhadap Implementasi Pembelajaran Daring di Sekolah Dasar," J. Ilmu Pendidik., vol. 2, no. 1, pp. 55-61, 2020.

[2] A. Sadikin and A. Hamidah, "Pembelajaran Daring di Tengah Wabah Covid-19 ( Online Learning in the Middle of the Covid-19 Pandemic )," J. Ilm. Pendidik. Biol., vol. 6, no. 1, pp. 214-224, 2020.

[3] Y. Fitriyani, I. Fauzi, and M. Z. Sari, "Motivasi Belajar Mahasiswa Pada Pembelajaran Daring Selama Pandemik Covid-19 Yani," J. Kependidikan J. Has. Penelit. dan Kaji. Kepustakaan di Bid. Pendidikan, Pengajaran dan Pembelajaran, vol. 6, no. 2, pp. 165-175, 2020.

[4] H. Putria, L. H. Maulana, and D. A. Uswatun, "Analisis Proses Pembelajaran Dalam Jaringan (DARING) Masa Pandemi COVID-19 pada Guru Sekolah Dasar,” J. Basicedu, vol. 4, no. 4, pp. 861-872, 2020, doi: 10.31004/basicedu.v4i4.460.

[5] Suid, A. Syafrina, and Tursinawati, "Analisis Kemandirian Siswa dalam Proses Pembelajaran di Kelas II SD Negeri 1 Banda Aceh,” J. Pesona Dasar, vol. 1, no. 5, pp. 70-81, 2017.

[6] Yamin, Desain Baru Pembelajaran Konstruktivistik. Jakarta: Referensi, 2012.

[7] N. Isnawati and Samian, "Kemandirian Belajar ditinjau dari Kreativitas Belajar dan Motivasi Belajar Mahasiswa," J. Penelit. Kemandirian Belajar, p. 128, 2018.

[8] I. D. Pratiwi and H. Laksmiwati, "Kepercayaan Diri dan Kemandirian Belajar pada Siswa SMA Negeri X," J. Psikol. Teor. dan Terap., vol. 7, no. 1, pp. 43-49, 2016.

[9] D. S. Zen and I. Fauziyah, "Hubungan antara Kemandirian Belajar dengan Disiplin Siswa," Pros. Semin. Nas. Pendidik. PGSD - Univ. Pakuan, pp. 94-99, 2018.

[10] Suparno and Suhaenah, Membangun Kompetensi Belajar. Jakarta: Pustaka Pelajar, 2001.

[11] R. Prayuda, "Pengaruh Kemandirian Belajar terhadap Hasil Belajar Siswa pada Mata Pelajaran Ekonomi di SMA," J. Untan, 2014. 
Journal UMGESHIC

Universitas Muhammadiyah Gresik Engineering, Social Science, and Health International Conference Vol 1 No 12021 